\title{
RUMAH FESYEN BERKELANJUTAN DI BANDUNG DENGAN PENDEKATAN EKOLOGI, SIMBIOSIS DAN METAFORA
}

\author{
Tjut Nabilla Zafriana ${ }^{1)}$, Rudy Trisno ${ }^{2)}$ \\ 1)Program Studi S1 Arsitektur, Fakultas Teknik, Universitas Tarumanagara, tjutnabilla@gmail.com \\ 2) Program Studi S1 Arsitektur, Fakultas Teknik, Universitas Tarumanagara, rudyt@ft.untar.ac.id
}

Masuk: 04-07-2021, revisi: 14-08-2021, diterima untuk diterbitkan: 23-10-2021

\begin{abstract}
Abstrak
Dengan meningkatnya kebutuhan manusia yang disebabkan dengan perkembangan populasi manusia, muncul berbagai fenomena. Tekstil, sebagai salah satu kebutuhan masyarakat yang digunakan sebagai pakaian juga terus meningkat. Perkembangan zaman dan tren yang terus diperbarui, memunculkan fenomena fast fashion dan budaya konsumtif yang menyebabkan menumpuknya limbah fesyen. Proyek Rumah Fesyen Berkelanjutan di Bandung ini bertujuan untuk mengembangkan hasil fesyen daur ulang dan juga mengurangi sifat konsumtif dengan memerbaiki baju menyesuaikan tren yang saat itu terjadi dengan mengangkat lokalitas yang hampir punah. Metode yang digunakan adalah metode simbiosis dan metafora dari selendang dengan pendekatan arsitektur neo-vernakular Sunda. Kesimpulannya adalah mewadahi segala kegiatan daur ulang fesyen menjadi sesuatu hal yang bernilai tinggi. Selain itu juga mengajak masyarakat dan komunitas fesyen untuk menampung dan mengolah pakaian bekas sehingga dapat dijual kembali maupun untuk dirinya sendiri. Kebaruan proyek ini adalah memberikan wadah untuk masyarakat umum Bandung untuk mengelola berbagai kegiatan yang berhubungan dengan fesyen.
\end{abstract}

Kata kunci: Ekologi; Fesyen; Metafora; Neo-Vernakular; Simbiosis

\begin{abstract}
With the increase in human needs caused by the development of the human population, various phenomena arise. Textiles, as one of the needs of the community that are used as clothing, also continue to increase. The development of the times and trends that are constantly updated, give rise to the phenomenon of fast fashion and consumptive culture which causes the accumulation of fashion waste. The Sustainable Fashion House project in Bandung aims to develop recycled fashion products and also reduce consumptive nature by improving clothes according to current trends by elevating localities that are almost extinct. The method used is the symbiotic method and the metaphor of the scarf with a Sundanese neo-vernacular architectural approach. The conclusion is to accommodate all fashion recycling activities into something of high value. In addition, it also invites the public and the fashion community to accommodate and process used clothes so that they can be resold as well as for themselves. The novelty of this project is to provide a platform for the general public of Bandung to manage various activities related to fashion.
\end{abstract}

Keywords: Ecology; Fashion; Metaphor; Neo-Vernacular; Symbiosis

\section{PENDAHULUAN}

\section{Latar Belakang}

Saat ini, semakin bertambahnya populasi dunia, kebutuhan manusia ikut bertambah. Munculnya berbagai fenomena seperti fenomena fast fashion untuk memenuhi kebutuhan sandang dan gaya hidup manusia cenderung merugikan lingkungan. Fesyen merupakan suatu gaya atau penampilan yang digunakan seseorang. Sedangkan, fast fashion adalah busana yang diproduksi dengan cepat. 
Fast Fashion cenderung lebih murah dan terus memperbarui mengikuti tren yang ada. Penggunaan material fast fashion yang tidak ramah lingkungan berdampak pada pencemaran lingkungan. Material yang tidak dapat terurai menyebabkan menumpuknya limbah fesyen (Kompas, 2018). Budaya konsumtif manusia yang mengganti dan membeli pakaian baru untuk terus mengikuti tren juga merupakan salah satu penyebab menumpuknya limbah fesyen. Sedangkan tren fesyen cenderung berulang disetiap tahunnya, sehingga pakaian yang yang sudah tertinggal zaman masih bisa digunakan kembali (Green Fashion Week, 2016).

Peningkatan kebutuhan pakaian, sifat masyarakat yang konsumtif dan selalu mengikuti tren menjadi salah satu faktor yang membuat tekstil termasuk limbah industri terbanyak. Dengan timbulnya bergbagai permasalahan lingkungan saat ini, manusia harus terus beradaptasi dan bertindak. Kesadaran dan partisipasi manusia sangat dibutuhkan untuk terus menanggapi kerusakan ekologi saat ini. Pemanfaatan limbah fesyen dapat dilakukan dengan mendaur ulang pakaian bekas menjadi suatu hal baru dan bernilai lebih tinggi, yang berkaitan dengan fesyen. Bandung sebagai kota mode di Pulau Jawa dengan industri fashionnya yang terus berkembang menjadi pilihan lokasi proyek. Dengan ini diharapkan dapat memberikan desain dan program yang dapat memberikan solusi terhadap fenomena fast fashion yang terdapat di Kota Bandung.

\section{Rumusan Permasalahan}

Bagaimana mengatasi permasalahan fast fashion yang ada di Bandung? Bagaimana sebagai arsitek menghasilkan desain arsitektur yang menjawab isu beyond ecology? Bagaimana penerapan simbiosis, ekologi dan metafora dalam bangunan?

\section{Tujuan}

Proyek ini bertujuan bagaimana sebuah bangunan arsitektur dapat memberikan kualitas ruang/wadah dan program yang dapat menjawab percepatan perkembangan fesyen. Dengan proyek ini, diharapkan dapat mengurangi limbah industri tekstil pada suatu kota, mengembangkan kreativitas dan keterlibatan manusia untuk menciptakan fesyen dengan ciri khas tersendiri dan dapat mengatasi permasalahan ekologi yang berkaitan dengan permasalahan fesyen pada daerah tersebut.

\section{Lokasi}

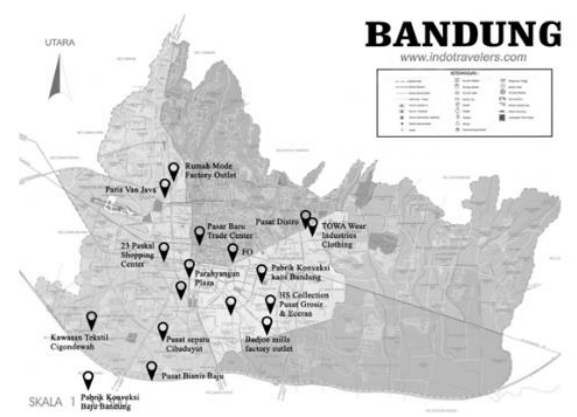

Gambar 1. Penyebaran Fasilitas Fesyen di Bandung

Sumber: www.indotravelers.com (2021)

Kawasan yang dipilih untuk perancangan di Kota Bandung. Bandung dikenal sebagai kota Mode dipulau Jawa. Selain itu, komunitas kreatif Bandung cukup aktif, terutama pada bidang fesyen. Banyak komunitas fesyen di Bandung yang bermunculan. Kawasan yang terpilih dekat dengan area perkembangan fesyen di bandung dan bangunan komunitas kreatif lainnya, serta dekat dengan pasar baju bekas kota Bandung (Gambar 1). 


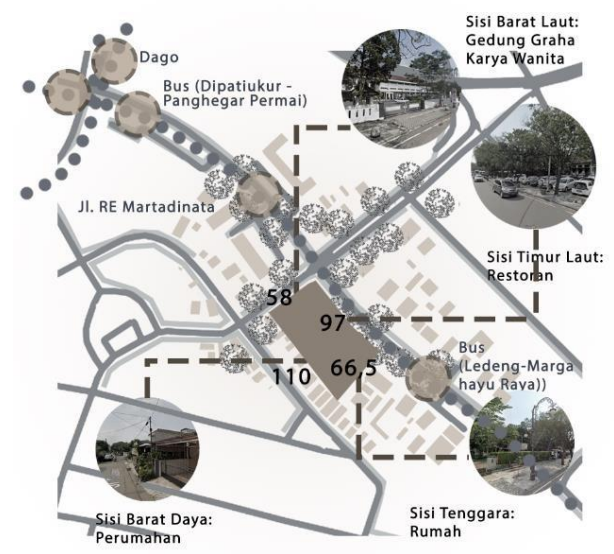

Gambar 2. Penyebaran Fasilitas Fesyen di Bandung Sumber: Ilustrasi Penulis (2021)

Kawasan terpilih terletak di Jl. LLRE Martadinata, memiliki kondisi yang cukup ramai, berdekatan dengan beberapa factory outlet, mall dan hotel di Kota Bandung. Kawasan ini terkenal sebagai pusat fashion dan kuliner bagi Kota Bandung menjadikan kawasan ini cukup strategisdengan fasilitas umum lainnya (Gambar 2).

Bangunandikelilingi bangunan komersil dan perkantoran. Tapak merupakan lahan kosong dan bangunan yang tidak terpakai. Lingkungan sekitar tapak memiliki ketinggian 2-3 lantai. Tapak menghadap ke timur laut. Lokasinya terletak di tengah perempatan antara Jalan RE Martadinata dan Jalan Cihapit.

\section{KAJIAN LITERATUR}

\section{Rumah Fesyen Berkelanjutan}

Rumah dapat diartikan sebagai sebuah tempat di mana penghuninya akan mendapat perlindungan. Rumah juga merupakan sesuatu yang dijadikan tempat beristirahat penghuninya yang telah melakukan berbagai macam aktivitas (Adhyaksa, 2021).

Menurut Troxell dan Stone dalam bukunya Fashion Merchandising, fashion di definisikan sebagai gaya yang diterima dan digunakan oleh mayoritas anggota sebuah kelompok dalam satu waktu tertentu (Fashion Magz, 2011). Fesyen berkelanjutan adalah kegiatan yang menyatukan segala beragam industri fesyen untuk bekerja sama mengubah sistem produksi, konsumsi, dan sumber fesyen kearah yang lebih baik lagi (Henninger, Alevizou, \& Oates, 2016). Dalam proyek ini, rumah fesyen berkelanjutan adalah tempat dimana masyrakat bandung dan komunitas fesyen Bandung dapat memproduksi dan mengolah kembali hal-hal yang berkaitan dengan fesyen.

\section{Ekologi}

Ekologi adalah ilmu interaksi antara segala jenis makhluk hidup dan lingkungannya. Berdasarkan dari bahasa Yunani "oikos" yang berarti rumah tangga atau bertempat tinggal dan "logos" berarti ilmu atau ilmiah. Maka ekologi memiliki definisi sebagai ilmu yang mempelajari hubungan timbal balik antara makhluk hidup dengan lingkungan (Setiawan, 2021).

Heinz Frick (1988) mengatakan bahwa, arsitektur ekologi tidak menentukan terhadap apa yang seharusnya terjadi dalam arsitektur, dikarena tidak ada sifat khas yang menjadikan sebagai standar. Akan tetapi mengenai keselarasan/keseimbangan antara manusia dan alam. Arsitektur ekologi mencangkup juga dimensi ruang, alam, waktu, sosiokultural dan teknik bangunan. Karena itu arsitektur ekologi memiliki istilah holistik yang berarti sangat luas dan mengandung semua unsur (Frick \& Suskiyatno, 2007). 
Melampaui ekologi berdasarkan kuliah Alvin Hadiwono (2021); bagaimana manusia memandang alam dan menyelesaikan permasalahannya dari sudut pandang alam. Sedangkan menurut kuliah Agustinus Sutanto (2021); melampaui ekologi disebabkan percepatan dan kecepatan waktu pada alam dan formasi sosial. Melampaui ekologi mencakup aspek teknologi, adaptasi, energi dan emisi, sustainable, resilience, dan juga konteks. Menurut penulis, melampaui ekologi menuju arsitektur adalah dengan membentuk fungsi yang mengadaptasi ekosistem yang saat ini terjadi melalui kualitas bangunan yang dapat menjawab isu atau permasalahan lingkungan saat ini.

\section{Simbiosis}

Simbiosis diartikan sebagai hubungan yang saling membutuhkan, sebagai tatanan dunia baru harus benar-benar digunakan untuk menggambarkan bentuk hubungan antara dua elemen dasar yang berbeda yang saling eksklusif. 'Simbiosis Dalam Arsitektur' Kisho Kurokawa merupakan penggabungan beberapa aspek yang berbeda dalam ruang lingkup arsitektural (Kurokawa, 1991). Secara filosofis, simbiosis adalah percampuran dua unsur budaya yang berbeda dalam satu entitas, yang didalamnya kedua unsur tersebut masih independen, namun saling menguntungkan antara satu dengan yang lainnya (Wuaten, Siregar, \& Takumansang, 2014).

Dalam bangunan ini, yang disimbiosiskan adalah antara fesyen dan arsitektur. Fesyen dan arsitektur merupakan hal yang berbeda, namun memiliki beberapa kesamaan. Zaha Hadid mengatakan: "Baik arsitektur maupun fashion sama-sama didasarkan pada struktur dan membentuk dan mengubah kebutuhan dasar (seperti pakaian dan tempat tinggal) menjadi seni". Dalam buku yang berjudul The Eyes of the Skin: Architecture and the Senses, karya Juhani Pallaasma, juga dikatakan bahwa baik arsitek maupun perancang busana merancang karyanya bukan untuk digunakannya sendiri, melainkan untuk orang lain yang menggunakannya, serta sebagai karya seni bagi orang lain yang melihatnya (Farahat , 2014).

Persamaan antara arsitektur dan fesyen diantaranya yaitu, keduanya memiliki hubungan erat dengan seni, sains dan teknologi. Selain itu, fesyen dan arsitektur sama-sama memberi wadah dan sebagai tempat berlindung pada manusia. Dalam proyek ini, arsitektur berperan memberi wadah untuk segala kegiatan yang terkait dengan fesyen yang berkelanjutan dan kegiatan daur ulang fesyen.

\section{Metafora}

Menurut Anthony C. Antoniades, 1990 dalam "Poetic of Architecture" Metafora adalah suatu cara memahami suatu hal, seolah hal tersebut sebagai suatu hal yang lain sehingga bisa mempelajari pemahaman yang lebih baik dari suatu topik dalam pembahasan. Arsitektur metafora adalah suatu gaya arsitektur yang mengambil dari bentuk sesuatu (Arsitur Studio, 2020). Metode Perancangan yang digunakan adalah metode metafora teraba, dimana wujudnya menyerupai ataupun terlihat secara visual dengan aslinya.

\section{METODE}

Metode yang digunakan adalah kualitatif berdasarkan teori pada kajian literatur dengan memperhatikan poin:

1. Ekologi

2. Simbiosis pada bangunan

3. Penerapan metafora pada bangunan 


\section{DISKUSI DAN HASIL}

\section{Ekologi}

Aspek ekologi yang pertama pada bangunan terletak dalam program bangunan. Program bangunan bertujuan mewadahi dan merangkul masyarakat dan komunitas fesyen untuk mendaur ulang kembali baju bekas menjadi sesuatu yang bernilai dan mengembangkan ecofashion di Bandung. Pengolahan daur ulang bisa berupa recycle maupun upcycle menjadi sesuatu yang lebih bernilai. Berikut merupakan fungsi utama dari Bangunan ini:

a. Workshop Area:

Menyediakan ruang untuk memproduksi barang-barang fesyen tersebut, dan menyediakan ruangan untuk workshop mengenai fashion tersebut. Masyarakat dan komunitas fesyen bebas datang dan memproduksi pakaian sendiri dengan menggunakan bahan bekas yang disediakan. Ruang yang disediakan berupa ruang menjait, ruang pemotongan bahan dan printing.

b. Ruang Komunitas Fesyen

Tempat komunitas fashion berkumpul agar bisa menambah ilmu pengetahuan atau berbagi ide baru dan mengadakan kolaborasi untuk menggembangkan fesyen lokal. Ruangan berbentuk seperti coworking space dan ruang diskusi untuk komunitas fesyen.

c. Galeri dan Studio Foto

Merupakan area pameran yang emmamerkan hasil produksi komunitas fesyen maupun halhal yang berkaitan dengan fesyen yang berkelanjutan maupun limbah fesyen.

d. Pasar Fesyen

Menjual barang bekas atau hasil produksi yang dibuat oleh komunitas fesyen dan desainerdesainer di Bandung

e. Gudang dan Area Cuci

Pakaian bekas yang dikumpulkan, diletakkan di Gudang penyimpanan dan di cuci, sebagai bahan atau material baru atau yang kondisinya masih layak dapat dijual kembali di thrift shop. Ruang laundry berguna untuk mencucui pakaian bekas yang akan diolah kembali ataupun dijual kembali. Pakaian bekas yang tidak layak dijual kembali, dikumpulkan menjadi bahan dasar baru untuk pengolahan baju.

Baju bekas yang tidak layak digunakan maupun didaur ulang menjadi sesuatu yang bernilai lebih tinggi dapat dijadikan sebagai rak penyimpanan atau partisi.

Pendekatan Ekologi yang kedua adalah dengan penggunaan material pada bangunan. Material yang digunakan ramah lingkungan, seperti menggunaan kaca low-e (low-e coated glass) yaitu merupakan kaca dengan emisivitas rendah, yang berfungsi untuk memfilter panas matahari. Selain itu, dengan memaksimalkan ventilasi silang sehingga sirkulasi udara dapat mengalir dengan baik. Ventilasi silang menyesuaikan dengan arah mata angin pada tapak.

\section{Simbiosis (Hubungan antara Arsitektur dan Fesyen)}

Arsitektur dan Fesyen memiliki berbagai kesamaan, yaitu sama-sama menggunakan metode dalam mendesain. Keduanya juga sama-sama berubah dipengaruhi waktu, budaya, dan masyarakat serta memberikan solusi yang ekologis terhadap bangunan. Dalam proyek ini, arsitektur sebagai menampung wadah aktivitas fesyen dengan tema sustainable, dari arsitekturnya maupun fashionnya tersebut.

Pada proyek ini, hubungan yang diambil antara arsitektur dan fesyen adalah skin. Sifat skin adalah bagaimana dia melindungi didalamnya, namun memungkinkan untuk bernafas dan menyerap yang ada di luar. Kulit bersifat fleksibel. Dalam arsitektur, skin bagaikan suatu fasad yang melindungi fungsi di dalamnya, sedangkan pakaian adalah skin kedua bagi manusia yang melindungi kulit asli pada manusia (Gambar 3). 

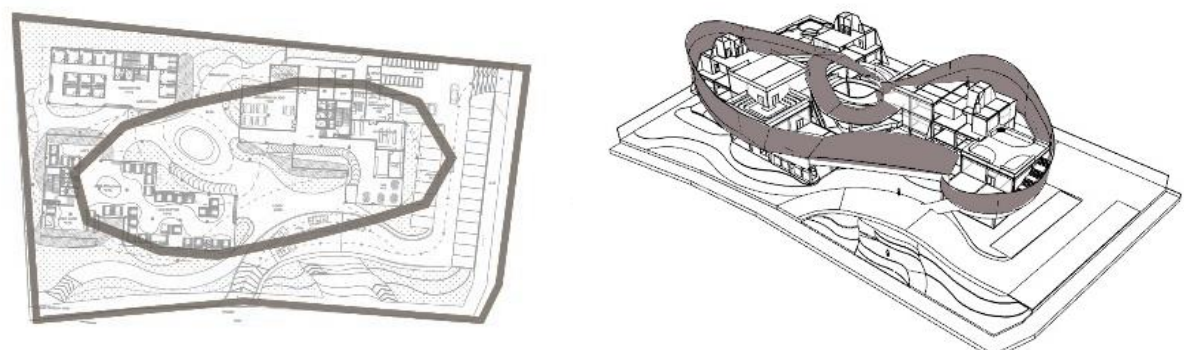

Gambar 3. Selendang sebagai second skin

Sumber: Ilustrasi Penulis (2021)

\section{Peggunaan Metode Metafora}

Bentuk metafora yang dipilih adalah bentuk metafora dari selendang. Selendang sebagai aksesoris pakaian tradisional Indonesia yang hampir setiap daerahnya memiliki ciri khas masingmasing. Selendang memiliki sifat yang fleksibel, multifungsi, dapat menyesuaikan bentuk, dapat digunakan untuk menutupi tubuh, menggendong anak, dan membawa barang. Saat ini selendang sudah jarang digunakan oleh masyarakat. Pemilihan selendang dengan motif batik khas Bandung sebagai konsep bangunan bertujuan untuk mengangkat kembali salah satu aksesoris atau pakaian adat yang sudah ditinggalkan (Gambar 4).

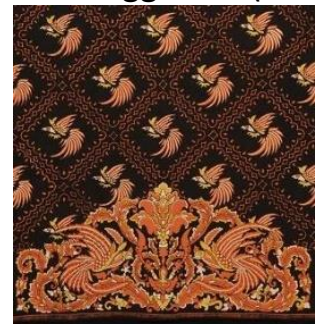

Gambar 4. Batik Bandung Motif Jalak Harupat

Sumber: http://balareabatikjabar.org

Bentuknya merupakan satu selendang yang saling bertemu dibagian akhirnya, mengalir menjadi satu kesatuan, dari menutupi bangunan sebagai fasad, hingga menjadi penutup atap. Bentuk disesuaikan dengan arah matahari dan arah mata angin, memaksimalkan pencahayaan alami dan ventilasi silang sesuai dengan kebutuhan ruang (Gambar 5).
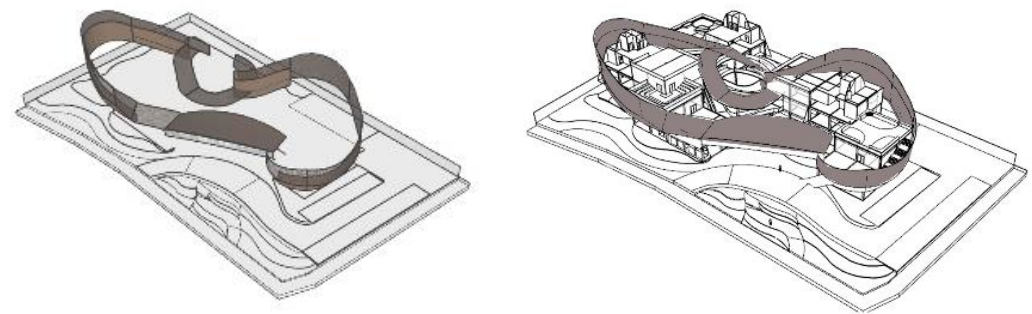

Gambar 5. Selendang Pada Bangunan Sumber: Ilustrasi Penulis (2021)

Penggunaaan ramp pada bangunan mengadaptasi bentuk dari selendang, memberi pengalaman dengan melihat, menjelaskan proses baju bekas dari komunitas, area workshop hingga pameran (Gambar 6 dan 7). 


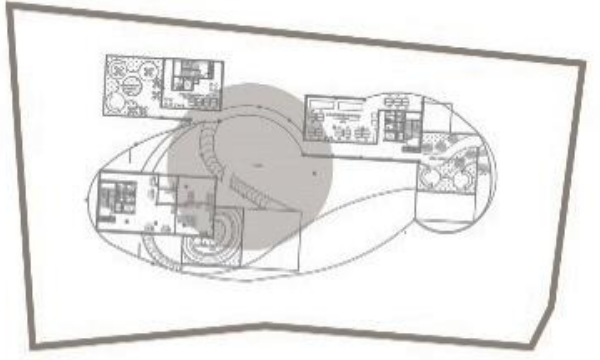

Gambar 6. Ramp pada Bangunan sebagai selendang Sumber: Ilustrasi Penulis (2021)

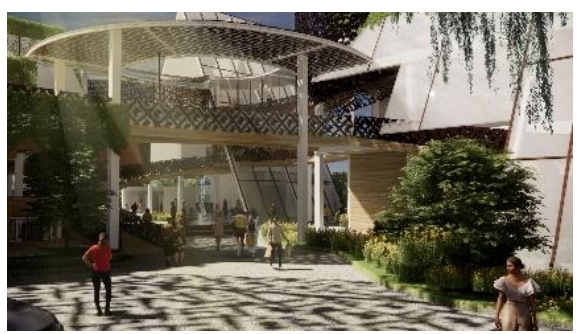

Gambar 7. Ramp pada bangunan Sumber: Penulis (2021)

Metode metafora ini digabung dengan pendekatan arsitektur neo-vernakular Sunda, karena tapak terletak di Bandung dengan masyarakat yang dominan merupakan masyarakat Sunda. Dengan penggabungan ini, diharapkan proyek ini dapat mengangkat lokalitas dan identitas fesyen maupun arsitektur khas Bandung.

Bentuk atap mengadaptasi bentuk atap arsitektur sunda, yaitu atap Jolopong. Massa dibuat terpisah dan menyatu dengan alam, dengan pola mengitari pusat bangunan (ngariung). Tipologi denah berbentuk kotak, mengikuti ciri arsitektur neo-vernakular Sunda (Gambar 8 dan 9).
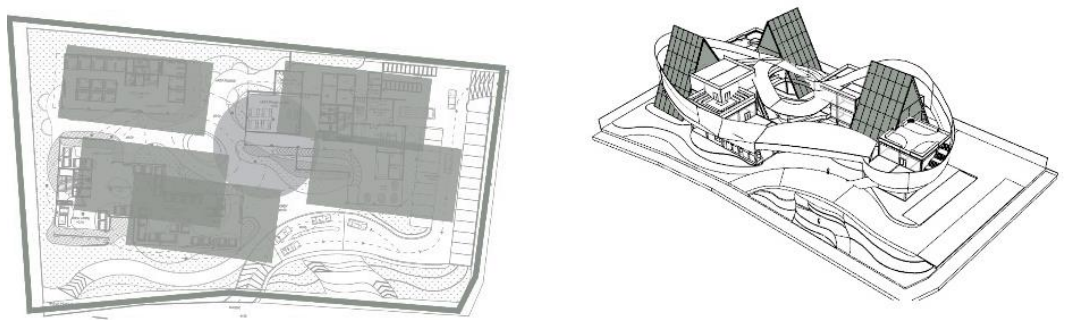

Gambar 8. Arsitektur Neo-Vernakular pada Bangunan Sumber: Ilustrasi Penulis (2021)
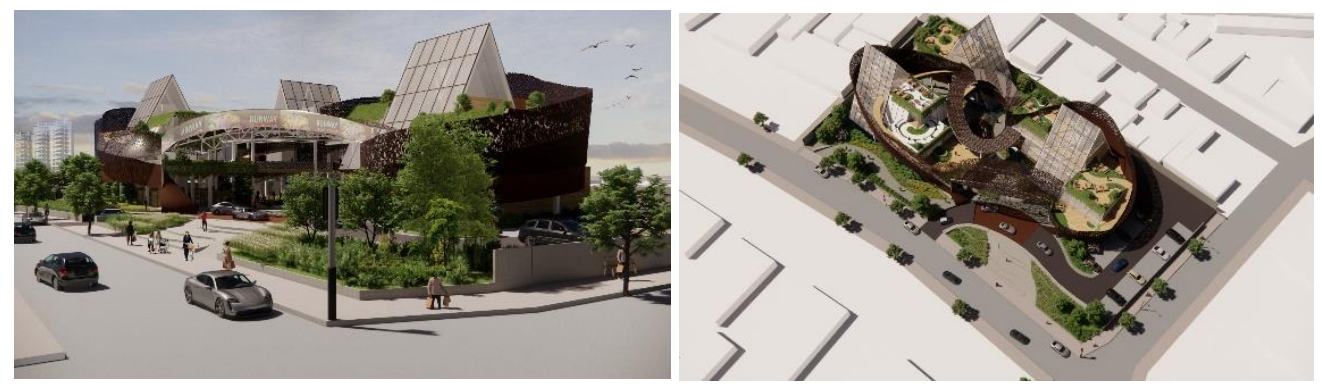

Gambar 9. Perspektif Selendang pada Bangunan

Sumber: Ilustrasi Penulis (2021)

\section{KESIMPULAN DAN SARAN}

\section{Kesimpulan}

Berdasarkan hasil penjabaran, fenomena fast fashion dan budaya konstumtif manusia merupakan salah satu penyebab menumpuknya limbah tekstil. Peminat yang banyak, penggunaan material yang tidak ramah lingkungan dan perubahan tren yang cepat juga salah satu penyebabnya. Dengan tren yang sifatnya cenderung berulang, banyak baju yang masih layak pakai dan bisa dikembangkan kembali, namun terbuang dan merusak lingkungan. Saat ini, banyak komunitas-komunitas kreatif yang juga mengembangkan fesyen yang berkelanjutan dan ramah lingkungan. Oleh karena itu, proyek ini dirancang untuk mewadahi segala kegiatan yang berkaitan dengan fesyen berkelanjutan. Proyek ini mengajak komunitas dan masyarakat Bandung khususnya untuk bebas berkespresi dalam hal fesyen seraya mengurangi limbah 
fesyen. Penerapan ekologi pada bangunan dengan menampung dan mengolah pakaian bekas menjadi sesuatu yang bernilai lebih tinggi sehingga dapat dimanfaatkan kembali. Pendekatan simbiosis dan metafora terletak pada desain, menggabungkan fesyen dan arsitektur, menggunakan bentuk selendang dengan motif batik khas Bandung, yang bertujuan untuk mengangkat kembali lokalitas dan ciri khas fesyen tradisional Sunda yang sudah jarang digunakan.

\section{Saran}

Dalam memperbaiki ekologi alam, perlu adanya kontribusi masyarakat yang tinggi. Kesadaran diri dan partisipasi masyarakat sangat penting. Masyarakat dapat memanfaatkan hal-hal yang sudah tidak bisa digunakan menjadi sesuatu yang bernilai tinggi. Penyediaan wadah yang mengundang, mengajak, dan memudahkan masyarakat untuk berpartisipasi dan membantu memperbaiki dan mendaur ulang sangatlah penting. Dengan penerapan bangunan yang ramah lingkungan, menarik dan mengangkat lokalitas, tidak hanya membuat masyarakat lebih kreatif, namun juga dapat membuka lapangan pekerjaan baru.

\section{Referensi}

Adhyaksa. (2021, Mei 6). Definisi Rumah Sebagai Sebuah Bangunan untuk Tempat Tinggal. (Adhyaksa Persada Indonesia) Retrieved Juni 22, 2021, from https://www.adhyaksapersada.co.id/pengertian-rumah/

Arsitektur Metafora : Pengertian, Prinsip, Tokoh dan Karyanya. (2020). Retrieved Juli 3, 2021, from Arsitur Studio: https://www.arsitur.com/2018/09/arsitektur-metaforalengkap.html

Definisi Fashion. (2011). (Fashion Magz) Retrieved Maret 2021, from http://fmagz.blogspot.com/2011/12/definisi-fashion.html

Farahat , B. (2014). THE INTERRELATIONSHIP BETWEEN FASHION AND. Al-Azhar University Engineering Journal, JAUES, 1-3. Retrieved Februari 22, 2021, from https://www.bau.edu.Ib/BAUUpload/Library/Files/Architecture/Publications/THE\%20I NTERRELATIONSHIP\%20BETWEEN\%20FASHION\%20AND.pdf

Fast Fashion vs Slow Fashion. (2016, Oktober). Retrieved Februari 20, 2021, from Green Fashion Week: https://www.greenfashionweek.org/sustainability/fast-fashion-vs-slowfashion/.

Frick, H., \& Suskiyatno, F. (2007). Dasar-dasar eko arsitektur. Yogyakarta: Kanisius.

Henninger, C., Alevizou, P., \& Oates, C. (2016). What is sustainable fashion? Journal of Fashion Marketing and Management, 20 No.4, 400-416.

Kurokawa, K. (1991). Interculural Architeture - The Philosophy of Symbiosis. Tokyo: Markus Zhand.

Mode Pakaian yang Berubah Cepat dan Dampaknya Bagi Lingkungan. (2018, Januari 9). Retrieved Februari 20, 2021, from Kompas: https://lifestyle.kompas.com/read/2018/01/09/114700620/mode-pakaian-yangberubah-cepat-dan-dampaknya-bagi-lingkungan?nomgid=1\&page=all\#page1

Setiawan, P. (2021, Juni 17). Pengertian Ekologi dan Menurut Para Ahli. Retrieved Juni 25, 2021, from Guru Pendidikan: https://www.gurupendidikan.co.id/pengertian-ekologi/.

Wuaten, L., Siregar, F., \& Takumansang, E. (2014). GRAHA PECINTA ALAM (GRAPALA) 'SIMBIOSIS DALAM ARSITEKTUR, KISHO KUROKAWA'. Jurnal Arsitektur DASENG UNSRAT Manado, 89-90. Retrieved Juni 20, 2021, from https://ejournal.unsrat.ac.id/index.php/daseng/article/view/6018/pdf

Zahra, A. (n.d.). Apa Itu Fesyen Berkelanjutan (Sustainable Fashion)? (Zero Waste Indonesia) Retrieved Juni 20, 2021, from https://zerowaste.id/zero-waste-fashion/apa-itu-fesyenberkelanjutan-sustainable-fashion/ 